\title{
Nutrients Impact the Pathogenesis and Development of Colorectal Cancer
}

\author{
Wan Du Jing-Yuan Fang \\ Division of Gastroenterology and Hepatology, Shanghai Institute of Digestive Disease, \\ Renji Hospital, Shanghai Jiao Tong University School of Medicine, Shanghai, China
}

\author{
Key Words \\ Calcium $\cdot$ Colorectal cancer $\cdot$ Dietary fiber $\cdot$ Selenium $\cdot$ Vitamins
}

\begin{abstract}
Background: Colorectal cancer is a commonly diagnosed cancer and the cause of many cancer deaths worldwide. Nutrients might be crucial in the pathogenesis and development of colorectal cancer. Although a number of studies have demonstrated the potential effects of nutrients, many challenges still remain. Summary: A tremendous amount of research has emerged concerning the roles of nutrients in colorectal cancer during the past decades. Here, we review the latest research progress on nutrients, including vitamins, folic acid, calcium, selenium and dietary fiber, involved in colorectal cancer prevention. Key Message: Nutrients are commonly consumed in foods or dietary supplements. It is clear that nutrients could play an important role and influence colorectal cancer outcomes. The relationship between nutrients and colorectal risk is complex. Vitamins, folic acid, calcium, selenium and dietary fiber have been proposed as potential agents to prevent colorectal cancer. However, some studies found that these nutrients did not reduce the incidence of colorectal cancer. Practical Implications: The supplementary dose of nutrients, the length of time required to observe the effects and confounding factors during the study might influence the role of nutrients in the prevention of colorectal cancer. Therefore, more evidence from ongoing clinical trials with different population groups and longer follow-up periods is critical to determine the relationship between nutrients and colorectal cancer.




\section{Introduction}

Colorectal cancer is the third most commonly diagnosed cancer in males and the second in females, with an estimated 1.4 million cases and 693,900 deaths in 2012 [1]. The occurrence of colorectal cancer is associated with dietary factors. Some nutrients affect the pathogenesis and development of colorectal cancer. Nutrients involved in colorectal cancer prevention include vitamins, folic acid, calcium, selenium and dietary fiber.

\section{Vitamins A, C, D, E and Folic Acid}

Studies of the effectiveness of vitamins to prevent colorectal cancer are highly inconsistent and controversial (reviewed in [2]). Vitamins A, C and E are major antioxidant vitamins that have been proposed as potential agents to prevent colorectal cancer. Their beneficial effects involve inhibition of free radicals and reduction of oxidative damage to DNA [3,4]. However, some studies found that vitamins $\mathrm{A}, \mathrm{C}$ and $\mathrm{E}$ did not reduce the incidence of colorectal cancer $[5,6]$. Therefore, the potential effects of antioxidant vitamin supplementation on colorectal cancer require further study.

Several studies suggested that vitamin D levels were inversely related to the pathogenesis and development of colorectal cancer [7-11]. Vitamin D could reduce cell proliferation, inhibit angiogenesis, promote cell differentiation and stimulate apoptosis, thus reducing the risk of colorectal cancer [6]. A few randomized controlled trials failed to find a protective role of vitamin D intervention on colorectal cancer $[12,13]$. The reason may be that the low dose of vitamin $\mathrm{D}$ used did not increase the circulating serum levels of 25 -hydroxyvitamin $\mathrm{D}_{3}$ $\left[25(\mathrm{OH}) \mathrm{D}_{3}\right]$. In a meta-analysis, individuals who achieved $25(\mathrm{OH}) \mathrm{D}$ serum levels $\geq 33 \mathrm{ng} / \mathrm{ml}$ $(82 \mathrm{nmol} / \mathrm{l})$ had a $50 \%$ lower incidence of colorectal cancer [14]. Two meta-analyses showed that taking high doses of vitamin D (1,000-2,000 U/day) reduced the risk of colorectal cancer by $50 \%[14,15]$. Further studies of the exact doses of vitamin $\mathrm{D}$ required to prevent colorectal cancer are needed.

The effect of folic acid on colorectal cancer development remains controversial. Some studies reported that high levels of folic acid in the diet or blood inhibit the development of colorectal cancer $[16,17]$. In contrast, recent data suggest that dietary high folic acid might enhance colorectal cancer progression $[18,19]$. The underlying state of the tissue may affect the role of folic acid on colorectal cancer development. Some scholars have suggested that folic acid supplementation protection against colonic carcinogenesis might depend on the neoplastic status of the colorectal cancer. Folic acid supplementation would protect against carcinogenesis before neoplastic transformation, whereas supplementation after the formation of preneoplastic colonic lesions might increase the risk of colorectal cancer risk. The connection between folic acid and colorectal cancer carcinogenesis is possibly associated with nucleotide biosynthesis and DNA methylation [20,21].

\section{Calcium}

Calcium intake plays a crucial role in the prevention of colorectal cancer. Large prospective studies confirmed the inverse association between high doses of dietary calcium and the risk of colon cancer development $[22,23]$. Calcium reduces the risk of colorectal cancer by binding to toxic secondary bile acids and ionized fatty acids, forming insoluble soaps in the colon [6]. Calcium could also inhibit colorectal cancer development by reducing proliferation, stimulating differentiation and inducing apoptosis of the colonic mucosa [24, 
25]. However, some studies revealed that calcium supplements do not reduce the risk of colorectal cancer $[14,26]$. This inconsistency may reflect the doses of dietary calcium used and the length of the studies.

\section{Selenium}

Several studies have demonstrated a protective effect of selenium on colorectal carcinogenesis $[27,28]$. Selenium may invoke preventive mechanisms by enhancing immune cell activity as well as anti-oxidative and anti-inflammatory properties [29]. Potential gender differences in selenium metabolism might explain the controversial effect of selenium on colorectal cancer prevention identified in several studies [29-31]. Several randomized trials and observational studies found no clear association between selenium levels and the risk of colorectal cancer [32-34]. Long-term selenium supplementation may lead to an increase in side effects, including an increased incidence of diabetes [35]. Therefore, we do not advocate selenium supplementation for people with adequate selenium levels.

\section{Dietary Fiber}

Studies identified from a search of PubMed and several other databases demonstrated an inverse association between dietary fiber intake and risk of colorectal cancer [36-39], which suggested that high dietary fiber intake could prevent colorectal cancer. However, some cohort studies and randomized trials were equivocal. Prospective cohort studies found different associations with fiber intake between men and women [40,41]. A pooled analysis of two clinical trials indicated that men may obtain more benefits from dietary fiber than women [42]. These inconsistencies may be explained in part by lifestyle and dietary factors that are also associated with colorectal cancer.

\section{Conclusion}

Many studies have demonstrated the potential effects of nutrients in the prevention of colorectal cancer, but many challenges remain. Future studies and clinical trials must be conducted, with different population groups and longer follow-up periods, which will help determine the role of nutrients in the prevention of colorectal cancer.

\section{Disclosure Statement}

The authors declare no conflicts of interest.

\section{References}

1 Torre LA, Bray F, Siegel RL, Ferlay J, Lortet-Tieulent J, Jemal A: Global cancer statistics, 2012. CA Cancer J Clin 2015;65:87-108.

2 Masri OA, Chalhoub JM, Sharara AI: Role of vitamins in gastrointestinal diseases. World J Gastroenterol 2015; 21:5191-5209.

3 Kirkali G, Keles D, Canda AE, Terzi C, Reddy PT, Jaruga P, Dizdaroglu M, Oktay G: Evidence for upregulated repair of oxidatively induced DNA damage in human colorectal cancer. DNA Repair (Amst) 2011;10:11141120 . 
4 Xu X, Yu E, Liu L, Zhang W, Wei X, Gao X, Song N, Fu C: Dietary intake of vitamins A, C, and E and the risk of colorectal adenoma: a meta-analysis of observational studies. Eur J Cancer Prev 2013;22:529-539.

5 Bjelakovic G, Nikolova D, Simonetti RG, Gluud C: Antioxidant supplements for preventing gastrointestinal cancers. Cochrane Database Syst Rev 2008;3:CD004183.

6 Chan AT, Giovannucci EL: Primary prevention of colorectal cancer. Gastroenterology 2010;138:2029-2043.e10.

-7 Jenab M, Bueno-de-Mesquita HB, Ferrari P, van Duijnhoven FJ, Norat T, Pischon T, Jansen EH, Slimani N, Byrnes G, Rinaldi S, Tjønneland A, Olsen A, Overvad K, Boutron-Ruault MC, Clavel-Chapelon F, Morois S, Kaaks R, Linseisen J, Boeing H, Bergmann MM, Trichopoulou A, Misirli G, Trichopoulos D, Berrino F, Vineis P, Panico S, Palli D, Tumino R, Ros MM, van Gils CH, Peeters PH, Brustad M, Lund E, Tormo MJ, Ardanaz E, Rodríguez L, Sánchez MJ, Dorronsoro M, Gonzalez CA, Hallmans G, Palmqvist R, Roddam A, Key TJ, Khaw KT, Autier P, Hainaut P, Riboli E: Association between pre-diagnostic circulating vitamin D concentration and risk of colorectal cancer in European populations: a nested case-control study. BMJ 2010;340:b5500.

-8 Mezawa H, Sugiura T, Watanabe M, Norizoe C, Takahashi D, Shimojima A, Tamez S, Tsutsumi Y, Yanaga K, Urashima M: Serum vitamin D levels and survival of patients with colorectal cancer: post-hoc analysis of a prospective cohort study. BMC Cancer 2010;10:347.

-9 Ma Y, Zhang P, Wang F, Yang J, Liu Z, Qin H: Association between vitamin D and risk of colorectal cancer: a systematic review of prospective studies. J Clin Oncol 2011;29:3775-3782.

10 Gandini S, Boniol M, Haukka J, Byrnes G, Cox B, Sneyd MJ, Mullie P, Autier P: Meta-analysis of observational studies of serum 25-hydroxyvitamin D levels and colorectal, breast and prostate cancer and colorectal adenoma. Int J Cancer 2011;128:1414-1424.

-11 Touvier M, Chan DS, Lau R, Aune D, Vieira R, Greenwood DC, Kampman E, Riboli E, Hercberg S, Norat T: Metaanalyses of vitamin D intake, 25-hydroxyvitamin D status, vitamin D receptor polymorphisms, and colorectal cancer risk. Cancer Epidemiol Biomarkers Prev 2011;20:1003-1016.

12 Wactawski-Wende J, Kotchen JM, Anderson GL, Assaf AR, Brunner RL, O’Sullivan MJ, Margolis KL, Ockene JK, Phillips L, Pottern L, Prentice RL, Robbins J, Rohan TE, Sarto GE, Sharma S, Stefanick ML, Van Horn L, Wallace RB, Whitlock E, Bassford T, Beresford SA, Black HR, Bonds DE, Brzyski RG, Caan B, Chlebowski RT, Cochrane B, Garland C, Gass M, Hays J, Heiss G, Hendrix SL, Howard BV, Hsia J, Hubbell FA, Jackson RD, Johnson KC, Judd H, Kooperberg CL, Kuller LH, LaCroix AZ, Lane DS, Langer RD, Lasser NL, Lewis CE, Limacher MC, Manson JE; Women's Health Initiative Investigators: Calcium plus vitamin D supplementation and the risk of colorectal cancer. N Engl J Med 2006;354:684-696.

-13 Bjelakovic G, Gluud LL, Nikolova D, Whitfield K, Krstic G, Wetterslev J, Gluud C: Vitamin D supplementation for prevention of cancer in adults. Cochrane Database Syst Rev 2014;6:CD007469.

14 Gorham ED, Garland CF, Garland FC, Grant WB, Mohr SB, Lipkin M, Newmark HL, Giovannucci E, Wei M, Holick MF: Vitamin D and prevention of colorectal cancer. J Steroid Biochem Mol Biol 2005;97:179-194.

$\longrightarrow 15$ Tárraga López PJ, Albero JS, Rodríguez-Montes JA: Primary and secondary prevention of colorectal cancer. Clin Med Insights Gastroenterol 2014;7:33-46.

-16 Sanjoaquin MA, Allen N, Couto E, Roddam AW, Key TJ: Folate intake and colorectal cancer risk: a metaanalytical approach. Int J Cancer 2005;113:825-828.

17 Giovannucci E: Epidemiologic studies of folate and colorectal neoplasia: a review. J Nutr 2002;132(8 suppl):2350S-2355S.

18 Baggott JE, Oster RA, Tamura T: Meta-analysis of cancer risk in folic acid supplementation trials. Cancer Epidemiol 2012;36:78-81.

19 Cole BF, Baron JA, Sandler RS, Haile RW, Ahnen DJ, Bresalier RS, McKeown-Eyssen G, Summers RW, Rothstein RI, Burke CA, Snover DC, Church TR, Allen JI, Robertson DJ, Beck GJ, Bond JH, Byers T, Mandel JS, Mott LA, Pearson LH, Barry EL, Rees JR, Marcon N, Saibil F, Ueland PM, Greenberg ER; Polyp Prevention Study Group: Folic acid for the prevention of colorectal adenomas: a randomized clinical trial. JAMA 2007;297:2351-2359.

20 Farias N, Ho N, Butler S, Delaney L, Morrison J, Shahrzad S, Coomber BL: The effects of folic acid on global DNA methylation and colonosphere formation in colon cancer cell lines. J Nutr Biochem 2015;26:818-826.

21 Kim YI: Will mandatory folic acid fortification prevent or promote cancer? Am J Clin Nutr 2004;80:1123-1128.

22 Wu K, Willett WC, Fuchs CS, Colditz GA, Giovannucci EL: Calcium intake and risk of colon cancer in women and men. J Natl Cancer Inst 2002;94:437-446.

23 Cho E, Smith-Warner SA, Spiegelman D, Beeson WL, van den Brandt PA, Colditz GA, Folsom AR, Fraser GE, Freudenheim JL, Giovannucci E, Goldbohm RA, Graham S, Miller AB, Pietinen P, Potter JD, Rohan TE, Terry P, Toniolo P, Virtanen MJ, Willett WC, Wolk A, Wu K, Yaun SS, Zeleniuch-Jacquotte A, Hunter DJ: Dairy foods, calcium, and colorectal cancer: a pooled analysis of 10 cohort studies. J Natl Cancer Inst 2004;96:1015-1022.

-24 Fedirko V, Bostick RM, Flanders WD, Long Q, Shaukat A, Rutherford RE, Daniel CR, Cohen V, Dash C: Effects of vitamin D and calcium supplementation on markers of apoptosis in normal colon mucosa: a randomized, double-blind, placebo-controlled clinical trial. Cancer Prev Res (Phila) 2009;2:213-223.

25 Fedirko V, Bostick RM, Flanders WD, Long Q, Sidelnikov E, Shaukat A, Daniel CR, Rutherford RE, Woodard JJ: Effects of vitamin D and calcium on proliferation and differentiation in normal colon mucosa: a randomized clinical trial. Cancer Epidemiol Biomarkers Prev 2009;18:2933-2941.

26 Feig B, Berger D, Furnham G: Oncología quirúrgica. Madrid, Editorial Marbán Libros SL, 2005, p 212.

27 Peters U, Chatterjee N, Church TR, Mayo C, Sturup S, Foster CB, Schatzkin A, Hayes RB: High serum selenium and reduced risk of advanced colorectal adenoma in a colorectal cancer early detection program. Cancer Epidemiol Biomarkers Prev 2006;15:315-320. 
28 Reid ME, Duffield-Lillico AJ, Sunga A, Fakih M, Alberts DS, Marshall JR: Selenium supplementation and colorectal adenomas: an analysis of the Nutritional Prevention of Cancer trial. Int J Cancer 2006;118:17771781.

29 Peters U, Takata Y: Selenium and the prevention of prostate and colorectal cancer. Mol Nutr Food Res 2008; 52:1261-1272.

-30 Takata Y, Kristal AR, King IB, Song X, Diamond AM, Foster CB, Hutter CM, Hsu L, Duggan DJ, Langer RD, Petrovitch H, Shikany JM, Vaughan TL, Lampe JW, Prentice RL, Peters U: Serum selenium, genetic variation in selenoenzymes, and risk of colorectal cancer: primary analysis from the Women's Health Initiative Observational Study and meta-analysis. Cancer Epidemiol Biomarkers Prev 2011;20:1822-1830.

-31 Waters DJ, Chiang EC, Cooley DM, Morris JS: Making sense of sex and supplements: differences in the anticarcinogenic effects of selenium in men and women. Mutat Res 2004;551:91-107.

32 Lippman SM, Klein EA, Goodman PJ, Lucia MS, Thompson IM, Ford LG, Parnes HL, Minasian LM, Gaziano JM, Hartline JA, Parsons JK, Bearden JD 3rd, Crawford ED, Goodman GE, Claudio J, Winquist E, Cook ED, Karp DD, Walther P, Lieber MM, Kristal AR, Darke AK, Arnold KB, Ganz PA, Santella RM, Albanes D, Taylor PR, Probstfield JL, Jagpal TJ, Crowley JJ, Meyskens FL Jr, Baker LH, Coltman CA Jr: Effect of selenium and vitamin E on risk of prostate cancer and other cancers: the Selenium and Vitamin E Cancer Prevention Trial (SELECT). JAMA 2009;301:39-51.

33 Steinbrenner H, Speckmann B, Sies H: Toward understanding success and failures in the use of selenium for cancer prevention. Antioxid Redox Signal 2013;19:181-191.

34 Papaioannou D, Cooper KL, Carroll C, Hind D, Squires H, Tappenden P, Logan RF: Antioxidants in the chemoprevention of colorectal cancer and colorectal adenomas in the general population: a systematic review and meta-analysis. Colorectal Dis 2011;13:1085-1099.

-35 Rayman MP: Selenium and human health. Lancet 2012;379:1256-1268.

-36 Fu Z, Shrubsole MJ, Smalley WE, Ness RM, Zheng W: Associations between dietary fiber and colorectal polyp risk differ by polyp type and smoking status. J Nutr 2014;144:592-598.

-37 Aune D, Chan DSM, Lau R, Vieira R, Greenwood DC, Kampman E, Norat T: Dietary fibre, whole grains, and risk of colorectal cancer: systematic review and dose-response meta-analysis of prospective studies. BMJ 2011; 343:d6617.

-38 Murphy N, Norat T, Ferrari P, Jenab M, Bueno-de-Mesquita B, Skeie G, Dahm CC, Overvad K, Olsen A, Tjønneland A, Clavel-Chapelon F, Boutron-Ruault MC, Racine A, Kaaks R, Teucher B, Boeing H, Bergmann MM, Trichopoulou A, Trichopoulos D, Lagiou P, Palli D, Pala V, Panico S, Tumino R, Vineis P, Siersema P, van Duijnhoven F, Peeters PH, Hjartaker A, Engeset D, González CA, Sánchez MJ, Dorronsoro M, Navarro C, Ardanaz E, Quirós JR, Sonestedt E, Ericson U, Nilsson L, Palmqvist R, Khaw KT, Wareham N, Key TJ, Crowe FL, Fedirko V, Wark PA, Chuang SC, Riboli E: Dietary fibre intake and risks of cancers of the colon and rectum in the European Prospective Investigation into Cancer and Nutrition (EPIC). PLoS One 2012; 7:e39361.

-39 Galas A, Augustyniak M, Sochacka-Tatara E: Does dietary calcium interact with dietary fiber against colorectal cancer? A case-control study in Central Europe. Nutr J 2013;12:134.

-40 Nomura AM, Hankin JH, Henderson BE, Wilkens LR, Murphy SP, Pike MC, Le Marchand L, Stram DO, Monroe KR, Kolonel LN: Dietary fiber and colorectal cancer risk: the multiethnic cohort study. Cancer Causes Control 2007;18:753-764.

-41 Hansen L, Skeie G, Landberg R, Lund E, Palmqvist R, Johansson I, Dragsted LO, Egeberg R, Johnsen NF, Christensen J, Overvad K, Tjønneland A, Olsen A: Intake of dietary fiber, especially from cereal foods, is associated with lower incidence of colon cancer in the HELGA cohort. Int J Cancer 2012;131:469-478.

-42 Jacobs ET, Lanza E, Alberts DS, Hsu CH, Jiang R, Schatzkin A, Thompson PA, Martínez ME: Fiber, sex, and colorectal adenoma: results of a pooled analysis. Am J Clin Nutr 2006;83:343-349. 